\title{
华北引黄灌区粮食产量与农业土壤资源质量 时空分布特征
}

\author{
陶 雯 ${ }^{1}$, 张旭博 2,3 , 孙志刚 $2,3,4$, 李仕冀 ${ }^{2,3}$, 刘晓洁 ${ }^{2}$, \\ 张崇玉 ${ }^{1}$, 欧阳竹 2,3 , 成升鬼斗 2,3
}

(1. 贵州大学农学院, 贵阳 $550025 ; 2$. 中国科学院地理科学与资源研究所/生态系统网络观测

与模拟重点研究实验室, 北京 $100101 ; 3$. 中国科学院大学资源与环境学院, 北京 100049;

4. 中国科学院山东东营地理研究院,东营 257509)

\begin{abstract}
摘要：明确作物产量和土壤养分时空变异可以更好地掌握农田生产力和土壤质量情况, 对农 业资源合理配置以及提高生产力可持续性有着非常重要的意义。利用华北平原引黄灌区下游 农田作物产量数据和耕地质量监测数据, 对华北平原引黄灌区下游作物产量的演变以及有机 质和养分的空间分布进行分析，阐明该地区作物产量、土壤养分的空间分布特征。结果表明： 灌区的农田生产力水平存在显著的空间和时空差异。20世纪 80 年代末以来, 农田生产力水平 整体呈上升趋势, 冬小麦高产田分布在黄河下游北岸中部地区的齐河县和下游南岸三个县, 范 围是 6084.0 6861.0 kg/ $\mathrm{hm}^{2}$, 夏玉米产量空间分布整体上呈现出中间高两端低的特征, 其中齐河 县的产量最高, 为 $7524.0 \mathrm{~kg} / \mathrm{hm}^{2}$ 。灌区农田土壤有机质、氮、磷、钾养分具有明显的时空分布差 异, 有机质和速效钾含量最高的德州市分别为 $16.30 \mathrm{~g} / \mathrm{kg}$ 和 $202.40 \mathrm{mg} / \mathrm{kg}$, 全氮含量最高的淄博 市为 $1.17 \mathrm{~g} / \mathrm{kg}$, 有效磷含量最高的泰安市为 $34.56 \mathrm{mg} / \mathrm{kg}$ 。研究表明, 灌区的生产力水平一直不 断在提升, 仍有很大的增长空间。掌握养分分布特征和土壤肥力的空间差异来制定合理的施 肥措施, 可为今后该地区实现精准农业和高产稳产提供科学依据。
\end{abstract}

关键词: 引黄灌区; 粮食产量;土壤质量;有机质;土壤养分

华北平原作为东南亚最大的冲积平原之一，尤其是引黄灌区，地处亚热带和中温带 过渡带，农业资源条件较为优越，是中国重要的农业生产基地，被称为“中国的粮 仓” [1]。根据农业地域分异规律，中国综合农业区划将华北平原划分为一级农业区 ${ }^{[2]}$ ，其 产量水平会直接影响中国农业可持续发展和粮食安全。土壤资源是人类赖以生存的最重 要的生产资料和自然资源，作为农业的生产资料是可不断更新的，可以通过对土壤生产 力进行评价来分析土壤资源质量 ${ }^{[3]}$ 。作物产量作为土壤生产力的体现，具有显著的时空变 异性，这主要是多种变异因素综合作用的结果，尤其是土壤肥力 ${ }^{[4]}$ 。土壤肥力是土壤在一 定的生态系统内提供生命必需养分和生产生活物质的能力，决定了耕地土壤本身的优劣 状态，同时也是生产力水平的重要标志，决定了作物的产量，因而提高土壤肥力是确保 农业高产优质的基础 ${ }^{[5]}$ 。

收稿日期：2018-07-30；修订日期：2019-01-31

基金项目：国家重点研发计划（2017YFC0503805）; 中国科学院战略性先导科技专项（XDA19040303）; 中国科学院 重点部署项目 (ZDBS-SSW-DQC)

作者简介：陶雯（1991-），女，广西贺州人，硕士，研究方向为植物营养。E-mail: twen005@163.com

通讯作者：张旭博（1985-), 男, 陕西杨凌人，博士，助理研究员，研究方向为农业生态过程及模拟。 
20 世纪 80 年代以来土壤肥力及养分演变一直是学者们研究的重点, 研究内容主要是 要分析现状和不同因素影响下的演变规律 ${ }^{[6]}$ 及其空间变化特征等 ${ }^{[7]}$ 。随着地统计学在土壤 科学中的广泛应用，对产量和土壤养分的空间分布特征及其变异规律的探索也成为了热 潮。高祥照等 ${ }^{[8]}$ 在北京顺义精准农业示范区运用地统计学的方法研究土壤养分与作物产量 的空间变异特性，产量差异的主要原因是土壤养分分布的空间变异性，其中土壤全氮和 有机质含量的分布与作物产量的分布基本一致。赵艺等 ${ }^{[9]}$ 运用地统计学与 GIS 相结合的方 法对彭山县土地整理区产量和土壤养分空间变异特征以及它们之间的关系进行分析，该 区域作物产量与氮、磷和钾含量呈正相关, 因此, 该研究区土壤养分运移和管理是维持 或提高农作物产量的重要因素。另外, 有研究表明施肥量对于产量和土壤养分含量变化 的影响明显较大 ${ }^{[10]}$ 。宋小顺等 ${ }^{[11]}$ 在河南新乡运用统计方法分析 1986-2002 年无机养分投人 量对作物产量的变化的影响, 无机氮磷钾具有直接增产与互作增产的效应, 每增施纯 氮、 $\mathrm{P}_{2} \mathrm{O}_{5} 、 \mathrm{~K}_{2} \mathrm{O}$ 各 $1.00 \mathrm{~kg}$, 可分别增产 $11.60 \mathrm{~kg} 、 18.68 \mathrm{~kg}$ 及 $33.76 \mathrm{~kg}$, 土壤中养分逐步 提升, 有利于土壤肥力的提高。然而, 目前针对华北平原引黄灌区作物产量和土壤主要 养分元素的时空演变的研究还较少, 这限制了该地区作为粮食主产区今后农业资源合理 配置和生产力的可持续发展。

因此, 本文以华北平原引黄灌区下游为研究区, 基于最新的采样、测定结果和历史 统计数据, 系统地分析华北平原引黄灌区下游产量、有机质及养分状况和变化规律, 以 期为该地区农业资源合理配置, 以及今后精准施肥和农业管理提供科学依据。

\section{1 研究方法与数据来源}

\section{1 研究区概况}

研究区域位于华北平原山东省引黄灌区，地理位置为 $35^{\circ} 55^{\prime} 22^{\prime \prime} \sim 38^{\circ} 10^{\prime} 7^{\prime \prime} \mathrm{N} 、 115^{\circ} 27^{\prime}$ $54^{\prime \prime} 118^{\circ} 58^{\prime} 10^{\prime \prime} \mathrm{E}$ 之间。该区域属于暖温带季风气候，气候温和，雨量集中，四季分明， 降水量集中，6-8月降水量占全年降水量的 60\% 70\%。

\section{2 数据来源}

灌区农田生产力的数据来自农业部种植业管理司开发的县级农作物数据库（http:// 202.127.42.157/moazzys/nongqingxm.aspx), 数据库来源于《中国统计年鉴》《中国农业统 计资料》。为分析土壤质量的动态变化, 选择 1980 年第二次土壤普查时的数据与现状进 行比较, 华北平原引黄灌区土壤有机质和养分含量现状的数据来自 2016 年最新调研采样 数据 (图 1, 包含德州、滨州、济南、聊城、东营市), 采样按照中国生态系统研究网络 (CERN) 研究中心采集样品要求, 即 581 个样品, 农田表层样品采集层次为：0 15、 15 30 两层 (采样为 5 钻混合样)。采样时间是 2016年 11-12月, 采样点布设遵循随机和 等量的原则, 同级别样品应当有相似的等量个体组成, 保证相同的代表性, 采样点选在 被采土壤类型特征明显的地方, 地形相对平坦、稳定、植被良好的地点。部分数据自 《华北小麦玉米轮作区耕地地力》 ${ }^{[12]}$ 提取。

\section{3 研究方法}

\subsection{1 样品采集和项目测定的方法}

土样采集选定表层土壤，采集样品风干后，挑出根系等杂物，分别过 $1.0 \mathrm{~mm}$ 和 0.25 $\mathrm{mm}$ 的篮备用。土壤中有机质的含量由有机碳决定, 有机碳测定采用 “重铬酸钾容量 


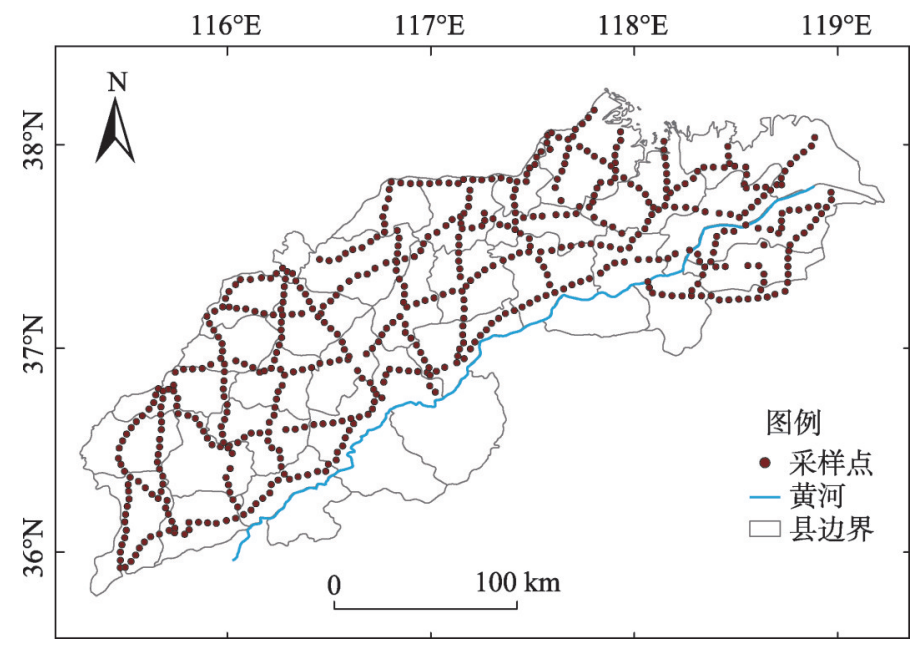

图 1 土壤养分分析样品采样点分布

Fig. 1 Distribution of the sampling sites for soil nutrients

法” ${ }^{[13]}$ ，全氮的测定方法为凯氏定氮法 ${ }^{[14]}$ ，有效磷的测定方法为 $\mathrm{NaHCO}_{3}$ 浸提一钼锑抗比 色法 ${ }^{[15]}$, 速效钾的测定方法为醋酸铵浸提火焰光度计法 ${ }^{[16]}$ 。

\subsection{2 数据分析}

本文采用 SPSS 22.0 和 Excel 2016 对数据进行统计分析和制图，运用 ArcGIS 10.0 为 平台将采样点和产量数据加载到 ArcGIS 中生成空间分布图。

有机质变异系数的计算公式 ${ }^{[17]}$ :

$$
C_{V}=(S D / \text { Mean }) \times 100 \%
$$

式中： $C_{V}$ 是变异系数 $(\%)$; $S D$ 是标准偏差 $(\mathrm{g} / \mathrm{kg})$; Mean 是平均值 $(\mathrm{g} / \mathrm{kg})$ 。 $C_{V}$ 的值越 小就说明该地区有机质分布的越稳定。同理可以计算全氮、有效磷和速效钾的变异系数。

\section{2 结果分析}

\section{1 灌区农田生产力时空变化}

\section{1 .1 农田生产力空间分布特征}

根据各县市统计的作物产量数据，整理制成黄河下游引黄灌区的农田生产力空间分 布图（图 2、图 3)。结果显示，冬小麦平均单产最高的是位于黄河下游北岸中部地区的 齐河县, 达 $6861.0 \mathrm{~kg} / \mathrm{hm}^{2}$, 其次是位于下游南岸的高青县、博兴县和邹平县, 均在 $6084.0 \mathrm{~kg} / \mathrm{hm}^{2}$ 以上; 中高产田主要分布黄河下游的北岸地区, 中产和低产田分布于鲁西 南和黄河南岸区域, 其中垦利县最低, 为 $4705.5 \mathrm{~kg} / \mathrm{hm}^{2}$ 。相对南岸灌区, 北岸农田生产 力普遍较高。

夏玉米平均单产呈现出中间高两端低的空间分布特征。其中，齐河县最高，为 $7524.0 \mathrm{~kg} / \mathrm{hm}^{2}$, 其次是位于下游南岸的高青县和邹平县, 均在 $6973.5 \mathrm{~kg} / \mathrm{hm}^{2}$ 以上; 中高 产田对称分布于黄河南北两岸，中产田分布于鲁西平原区，中低产田和低产田主要分布 于东部沿海地区和鲁西南黄河南岸区域，其中垦利县最低，为 $5092.5 \mathrm{~kg} / \mathrm{hm}^{2}$ 。

2.1.2 农田生产力的时间变化特征

由图 4 可知，华北引黄灌区农田生产力水平整体呈上升趋势，但同时存在显著的时 


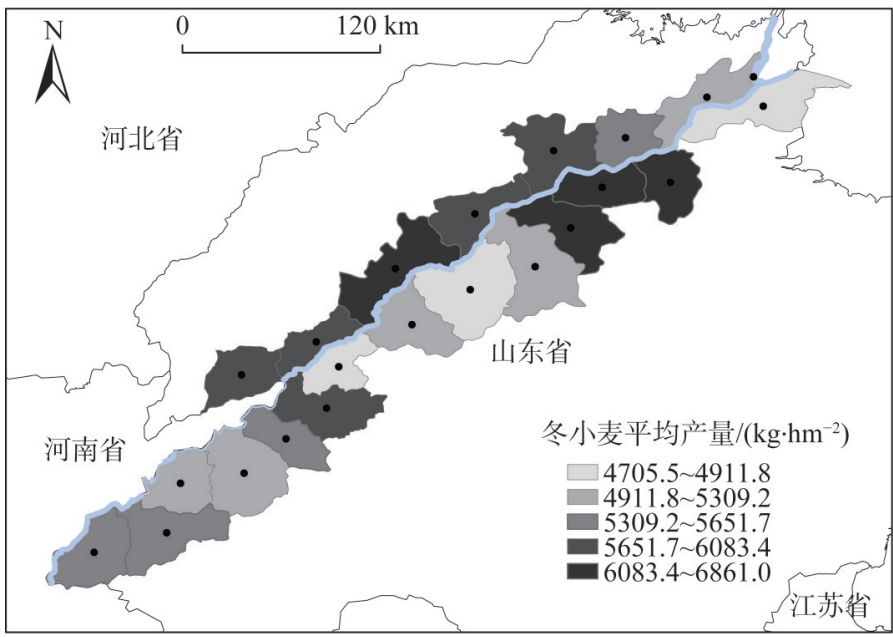

图 2 华北平原引黄灌区下游冬小麦多年平均产量

Fig. 2 Annual yield of winter wheat in the irrigation area at the lower reaches of the Yellow River in the North China Plain

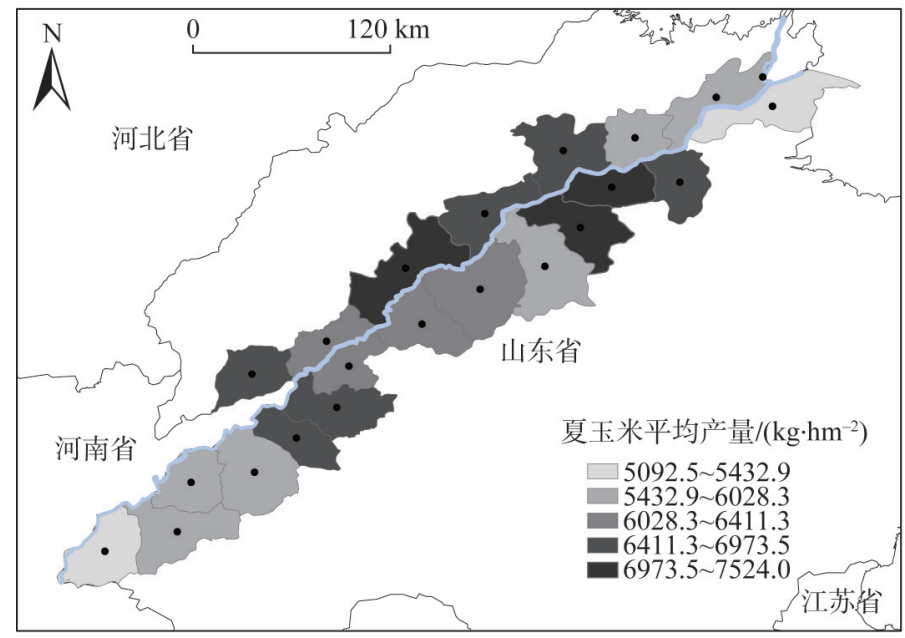

图 3 华北平原引黄灌区下游夏玉米多年平均产量

Fig. 3 Annual yield of summer maize in the irrigation area at the lower reaches of the Yellow River in the North China Plain

空差异性，可以总结为四种类型：（1）增长一停滞一增长型，如灌区最西部的牡丹区， 其单产从 1990 年的 $3930.0 \mathrm{~kg} / \mathrm{hm}^{2}$ 增长到 2000 年的 $5790.0 \mathrm{~kg} / \mathrm{hm}^{2}$ ，此后 5 年维持不变，从 2005 年又开始增长到 2011 年达 $6585.0 \mathrm{~kg} / \mathrm{hm}^{2}$, 具有相似变化特征的还有肥城市、禹城市 和章丘区; (2) 波动增长一快速增长型, 如阳谷县、陵县、邹平县和济阳县的农田粮食 单产均呈现前期波动增长，后期持续增长的两段式变化特征；（3）稳定一增长型，如茌 平县 2002 年前的粮食单产始终稳定在 $4950 \mathrm{~kg} / \mathrm{hm}^{2}$ ，此后进人快速增长阶段，到 2012 年 达 $7050.0 \mathrm{~kg} / \mathrm{hm}^{2}$; （4）快速增长一停滞型, 如桓台县, 粮食单产由 1988 年的 $5295.0 \mathrm{~kg} / \mathrm{hm}^{2}$ 增至 2000 年的 $8715.0 \mathrm{~kg} / \mathrm{hm}^{2}$ ，增长了 $64.5 \%$ ，而 2000 年后单产不再增长。

\section{2 灌区农田养分空间变化}

\subsection{1 华北地区引黄灌区土壤有机质含量}

华北平原引黄灌区不同地区有机质含量调查显示（表 1)，土壤有机质含量最高的是 

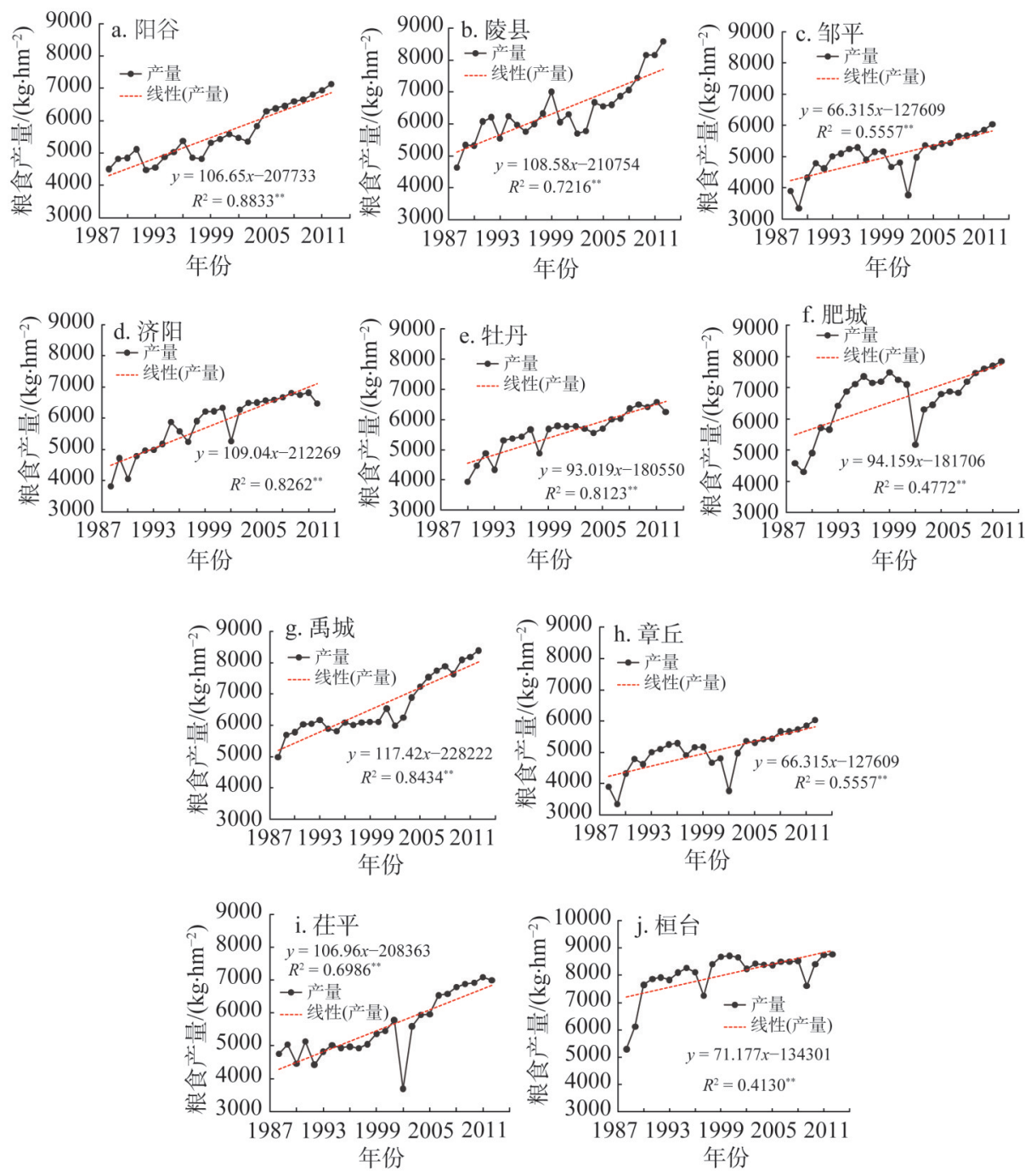

注: "表示显著水平为 0.01 。

图 4 灌区典型县农田粮食产量变化

Fig. 4 Change of grain yield of farmland in typical counties in the irrigation area

山东德州市, 为 $16.30 \mathrm{~g} / \mathrm{kg}$, 含量较低的是东营市, 为 $9.90 \mathrm{~g} / \mathrm{kg}$, 其余各市介于 $12.00 \sim$ $15.40 \mathrm{~g} / \mathrm{kg}$ 之间。土壤有机质含量变异系数最大的是东营市, 为 $39.1 \%$, 其余各市范围为 $21.4 \% \sim 35.0 \%$, 为中等强度变异。与 1980 年二次普查相比, 德州市提高 $5.47 \mathrm{~g} / \mathrm{kg}$, 淄 博、烟台市降低分别降低 $3.86 \mathrm{~g} / \mathrm{kg}$ 和 $6.24 \mathrm{~g} / \mathrm{kg}$, 其余各市变化不大。

\section{2 .2 华北地区引黄灌区土壤全氮含量}

华北平原引黄灌区不同地区中全氮含量调查显示（表1），山东淄博市的全氮含量最 高, 为 $1.17 \mathrm{~g} / \mathrm{kg}$, 含量较低的是东营市, 为 $0.60 \mathrm{~g} / \mathrm{kg}$, 其余各市介于 $0.74 \sim 1.02 \mathrm{~g} / \mathrm{kg}$ 之 间。土壤全氮含量变异系数最大的是济南市为 $53.7 \%$, 其余各市范围为 $19.9 \%$ 36.3\% , 属 中等强度变异。与 1980 年二次普查数据相比, 滨州、聊城和德州市分别提升 $0.23 、 0.24$ 和 $0.32 \mathrm{~g} / \mathrm{kg}$, 泰安和烟台分别降低 $0.17 \mathrm{~g} / \mathrm{kg}$ 和 $0.16 \mathrm{~g} / \mathrm{kg}$ ，其余各市变化不大。 
表 1980 年和 2016 年华北平原引黄灌区下游小麦玉米轮作区地级市耕层土壤有机质和全氮含量

Table 1 Soil organic and total nitrogen matter content in plough layer of wheat and maize rotation region in the irrigation area at the lower reaches of the Yellow River in the North China Plain in 1980 and 2016

\begin{tabular}{|c|c|c|c|c|c|c|c|c|c|c|}
\hline \multirow{3}{*}{ 地级市 } & \multicolumn{5}{|c|}{ 有机质 } & \multicolumn{5}{|c|}{ 全氮 } \\
\hline & \multicolumn{2}{|c|}{ 2016年 } & \multicolumn{2}{|c|}{ 1980年 } & \multirow{2}{*}{$\begin{array}{c}\text { 增减 } \\
\text { 幅度/\% }\end{array}$} & \multicolumn{2}{|c|}{ 2016年 } & \multicolumn{2}{|c|}{ 1980年 } & \multirow{2}{*}{$\begin{array}{c}\text { 增减 } \\
\text { 幅度/\% }\end{array}$} \\
\hline & $\begin{array}{l}\text { 均值/ } \\
(\mathrm{g} / \mathrm{kg})\end{array}$ & $\begin{array}{c}\text { 变异 } \\
\text { 系数 } / \%\end{array}$ & $\begin{array}{l}\text { 均值/ } \\
(\mathrm{g} / \mathrm{kg})\end{array}$ & $\begin{array}{c}\text { 变异 } \\
\text { 系数 } / \% \\
\end{array}$ & & $\begin{array}{l}\text { 均值/ } \\
(\mathrm{g} / \mathrm{kg})\end{array}$ & $\begin{array}{c}\text { 变异 } \\
\text { 系数/\% }\end{array}$ & $\begin{array}{l}\text { 均值/ } \\
(\mathrm{g} / \mathrm{kg})\end{array}$ & $\begin{array}{c}\text { 变异 } \\
\text { 系数/\% }\end{array}$ & \\
\hline 滨州市 & $13.30 \pm 4.6$ & 34.8 & $12.31 \pm 6.0$ & 49.0 & 8.0 & $0.97 \pm 0.3$ & 27.4 & $0.74 \pm 0.2$ & 30.0 & 31.1 \\
\hline 菏泽市 & $12.00 \pm 2.6$ & 21.4 & $15.14 \pm 7.0$ & 46.2 & -20.7 & $0.83 \pm 0.2$ & 22.9 & $0.90 \pm 0.4$ & 38.9 & -7.8 \\
\hline 济南市 & $14.80 \pm 4.0$ & 26.7 & $16.42 \pm 10.0$ & 61.0 & -9.9 & $0.74 \pm 0.4$ & 53.7 & $0.85 \pm 0.3$ & 34.3 & -12.9 \\
\hline 济宁市 & $14.70 \pm 4.4$ & 29.7 & $17.03 \pm 7.3$ & 43.4 & -13.7 & $0.95 \pm 0.3$ & 33.6 & $1.01 \pm 0.4$ & 35.6 & -5.9 \\
\hline 聊城市 & $13.80 \pm 3.7$ & 27.0 & $12.39 \pm 5.2$ & 42.1 & 11.4 & $1.02 \pm 0.3$ & 29.0 & $0.78 \pm 0.3$ & 34.6 & 30.8 \\
\hline 泰安市 & $14.80 \pm 5.2$ & 35.0 & $17.75 \pm 13.0$ & 73.4 & -16.6 & $0.90 \pm 0.2$ & 24.5 & $1.07 \pm 0.5$ & 50.7 & -15.9 \\
\hline 畄博市 & $15.40 \pm 4.5$ & 29.2 & $19.26 \pm 10.9$ & 56.6 & -20.0 & $1.17 \pm 0.4$ & 31.6 & $0.99 \pm 0.4$ & 41.0 & 18.2 \\
\hline 临沂市 & $13.60 \pm 3.3$ & 24.3 & $15.59 \pm 6.5$ & 41.7 & -12.8 & $0.90 \pm 0.2$ & 22.7 & $0.93 \pm 0.3$ & 32.5 & -3.2 \\
\hline 烟台市 & $13.50 \pm 3.6$ & 26.7 & $19.74 \pm 13.7$ & 69.5 & -31.6 & $0.90 \pm 0.2$ & 19.9 & $1.06 \pm 0.5$ & 50.6 & -15.1 \\
\hline 德州市 & $16.30 \pm 4.0$ & 24.6 & $10.93 \pm 3.4$ & 31.3 & 49.1 & $1.00 \pm 0.2$ & 21.4 & $0.68 \pm 0.2$ & 29.0 & 47.1 \\
\hline 东营市 & $9.90 \pm 3.8$ & 39.1 & $10.56 \pm 6.0$ & 56.7 & -6.3 & $0.60 \pm 0.2$ & 36.3 & $0.60 \pm 0.2$ & 34.5 & 0 \\
\hline
\end{tabular}

\section{2 .3 华北地区引黄灌区土壤有效磷含量}

华北平原引黄灌区不同地区中有效磷含量调查显示（表2)，山东泰安市的有效磷含 量最高为 $34.56 \mathrm{mg} / \mathrm{kg}$ ，含量较低的是东营市，为 $19.10 \mathrm{mg} / \mathrm{kg}$ ，其余各市介于 21.43 $33.70 \mathrm{mg} / \mathrm{kg}$ 之间。土壤有效磷含量变异系数最大的是东营市，为 $85.1 \%$, 其余各市范围 为 $50.9 \%$ 81.9\%，属中等强度变异。与 1980 年二次普查数据对比发现，各市有效磷含量 均降低，降低最多的是东营市，降低 $53.30 \mathrm{~g} / \mathrm{kg}$ 。

\section{表 21980 年和 2016 年华北平原引黄灌区下游小麦玉米轮作区地级市耕层土壤有效磷和速效钾含量}

Table 2 Effective phosphorus and available potassium content in plough layer of wheat and maize rotation region in the irrigation area at the lower reaches of the Yellow River in the North China Plain in 1980 and 2016

\begin{tabular}{|c|c|c|c|c|c|c|c|c|c|c|}
\hline \multirow{3}{*}{ 地级市 } & \multicolumn{5}{|c|}{ 有效磷 } & \multicolumn{5}{|c|}{ 速效钾 } \\
\hline & \multicolumn{2}{|c|}{ 2016年 } & \multicolumn{2}{|c|}{1980 年 } & \multirow{2}{*}{$\begin{array}{c}\text { 增减 } \\
\text { 幅度/\% }\end{array}$} & \multicolumn{2}{|c|}{ 2016年 } & \multicolumn{2}{|c|}{ 1980年 } & \multirow{2}{*}{$\begin{array}{l}\text { 增减 } \\
\text { 幅度/\% }\end{array}$} \\
\hline & $\begin{array}{l}\text { 均值/ } \\
(\mathrm{g} / \mathrm{kg})\end{array}$ & $\begin{array}{c}\text { 变异 } \\
\text { 系数 } / \%\end{array}$ & $\begin{array}{l}\text { 均值/ } \\
(\mathrm{g} / \mathrm{kg})\end{array}$ & $\begin{array}{c}\text { 变异 } \\
\text { 系数 } / \%\end{array}$ & & $\begin{array}{l}\text { 均值/ } \\
(\mathrm{g} / \mathrm{kg})\end{array}$ & $\begin{array}{c}\text { 变异 } \\
\text { 系数 } / \%\end{array}$ & $\begin{array}{l}\text { 均值/ } \\
(\mathrm{g} / \mathrm{kg})\end{array}$ & $\begin{array}{c}\text { 变异 } \\
\text { 系数 } / \%\end{array}$ & \\
\hline 滨州市 & $23.38 \pm 11.9$ & 50.9 & $65.03 \pm 26.6$ & 40.9 & -64.0 & $112.00 \pm 42.0$ & 37.4 & $168.63 \pm 80.1$ & 47.5 & -33.6 \\
\hline 菏泽市 & $21.43 \pm 11.2$ & 52.3 & $52.05 \pm 16.0$ & 30.6 & -58.8 & $102.00 \pm 38.0$ & 37.1 & $123.06 \pm 29.7$ & 24.1 & -17.1 \\
\hline 济南市 & $23.33 \pm 16.3$ & 70.0 & $49.39 \pm 22.5$ & 45.6 & -52.8 & $118.00 \pm 42.0$ & 35.2 & $114.76 \pm 29.1$ & 25.4 & 2.8 \\
\hline 济宁市 & $27.31 \pm 15.3$ & 56.0 & $54.11 \pm 18.4$ & 34.0 & -49.5 & $128.00 \pm 50.0$ & 39.3 & $118.33 \pm 32.8$ & 27.7 & 8.2 \\
\hline 聊城市 & $27.63 \pm 17.3$ & 62.6 & $51.89 \pm 16.3$ & 31.5 & -46.8 & $121.00 \pm 39.0$ & 32.5 & $107.09 \pm 23.2$ & 21.6 & 13.0 \\
\hline 泰安市 & $34.56 \pm 20.6$ & 59.6 & $47.45 \pm 18.8$ & 39.6 & -27.2 & $119.00 \pm 36.0$ & 30.7 & $100.0 \pm 29.44$ & 29.4 & 19.0 \\
\hline 畄博市 & $28.01 \pm 16.7$ & 59.8 & $44.04 \pm 17.1$ & 38.8 & -36.4 & $135.00 \pm 45.0$ & 33.1 & $117.18 \pm 32.7$ & 27.9 & 15.2 \\
\hline 临沂市 & $33.70 \pm 22.9$ & 68.0 & $46.49 \pm 19.1$ & 41.0 & -27.5 & $121.80 \pm 28.3$ & 23.2 & $99.37 \pm 26.0$ & 26.2 & 22.6 \\
\hline 烟台市 & $32.60 \pm 19.3$ & 59.1 & $52.25 \pm 26.5$ & 50.7 & -37.6 & $133.40 \pm 45.4$ & 34.1 & $99.66 \pm 48.8$ & 49.0 & 33.9 \\
\hline 德州市 & $33.10 \pm 27.1$ & 81.9 & $59.06 \pm 24.2$ & 41.0 & -44.0 & $202.40 \pm 78.8$ & 38.9 & $116.45 \pm 24.5$ & 21.0 & 73.8 \\
\hline 东营市 & $19.10 \pm 16.2$ & 85.1 & $72.40 \pm 27.3$ & 37.7 & -73.6 & $159.00 \pm 61.9$ & 38.9 & $205.00 \pm 92.8$ & 45.3 & -22.4 \\
\hline
\end{tabular}




\subsection{4 华北地区引黄灌区土壤速效钾含量}

华北平原引黄灌区不同地区中速效钾含量调查显示（表 2)，速效钾含量最高的是山 东德州市, 为 $202.40 \mathrm{mg} / \mathrm{kg}$, 含量较低的是菏泽市, 为 $102.00 \mathrm{mg} / \mathrm{kg}$, 其余各市介于 $112.00 \sim 159.00 \mathrm{mg} / \mathrm{kg}$ 之间。土壤速效钾含量变异系数最大的是济宁市为 $39.3 \%$, 其余各 市范围为 $23.2 \%$ 38.9\% , 属中等强度变异。与 1980 年二次普查数据相比，德州市提升 $85.95 \mathrm{mg} / \mathrm{kg}$, 滨州和东营市降低的较大, 分别为 $56.63 \mathrm{mg} / \mathrm{kg}$ 和 $46.00 \mathrm{mg} / \mathrm{kg}$, 其余各市 变化不大。

\section{3 结论与讨论}

\section{1 结论}

黄河下游引黄灌区的农田生产力水平存在显著的时空变异性。在空间上，冬小麦的 高产田主要分布在黄河下游北岸，北岸的农田生产力普遍高于南岸; 在时间上，20世纪 80 年代末以来，灌区内农田生产力水平整体呈上升趋势，不同地区的产量随时间变化的 特征出现了多种类型，体现了不同地区产量变化的不同步性。总的来说产量的空间变异 性主要受该地区成土母质和地域环境影响，时间上的变异主要是人类活动起主导因素。 灌区中农田土壤有机质和养分在不同地区的有显著的时空变异性，主要受地形和环境等 自然因素、作物产量以及人类活动的影响, 其中施肥措施、灌溉、耕作方式、秸秆还田 等农田管理措施对有机质和养分含量的变化有决定性的作用，同时影响着土壤的肥力， 对产量的提高也起到决定作用。

\section{2 讨论}

本研究的结果表明华北平原引黄灌区内作物产量存在显著的空间差异性，整体来说 北岸灌区产量比南岸高。有学者通过研究分析 1999-2000年位于黄河下游灌区北岸的山东 省䈐箕李引黄灌区夏玉米和冬小麦产量，发现其产量显示上游西南部最高、下游东北部 最低、中游地区起伏变化较大的空间分布特点 ${ }^{[18]}$ 。研究区作物产量随时间缓慢上升，主 要是因为该地区生产条件和管理水平不断提高，如作物品种改良 ${ }^{[19]}$ 、土壤盐碱化治理、 排水系统改善、化肥施用量增加 ${ }^{[1]}$ 、灌溉面积增加 ${ }^{[1]}$ 、有机肥配施有效改良土壤结构和提

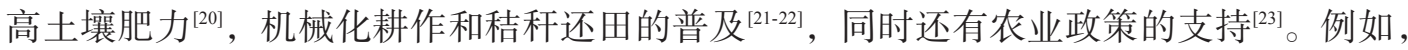
1988-1993 灌溉和排涝条件明显改善，农业科技投人（良种和化肥等），粮食年均增长率 达 $4.0 \%{ }^{[19]} ; 1980-2008$ 年间，化肥使用量增长了约 4 倍、灌溉面积增加了约 $20 \%$ 、作物品 种对气候适应性增强 ${ }^{[1]}$ 。因此，在华北平原引黄灌区通过合理施肥、增加有效灌溉面积、 选择改良品种以及进行秸秆还田和适宜的耕作方式等能够增加作物产量。

结果显示：1980-2016年，土壤有机质含量由西向东呈现中间高两端低的特征，且土 壤养分氮、磷、钾的分布都存在明显的空间差异。有学者发现山东省耕地土壤有机质、

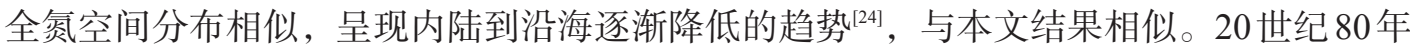
代至 2000 年，华北平原引黄灌区农田土壤盐碱减少了约 $70 \%$, 农田的排灌系统明显改 善, 肥料施用多样, 均影响了土壤有机质和养分的含量 ${ }^{[25-26]}$ 。位于华北平原引黄灌区的中 国科学院禹城综合试验站长期试验结果表明，长期平衡施用化肥条件下土壤有机质含量 持续增加，在 0 40 $\mathrm{cm}$ 土层中每年的增加速率达到 $182.8 \mathrm{~kg} \cdot \mathrm{C} / \mathrm{hm}^{2}$, 农田有机质提升潜力 可达到 $1.6 \times 10^{9} \sim 2.4 \times 10^{9} \mathrm{~kg} \cdot \mathrm{C} / \mathrm{a}^{[27]}$ 。另外，由于华北平原引黄灌区氮、磷、钾施用量变化 差异明显, 不合理施肥和管理导致氮、磷、钾养分利用率很低且变幅很大, 这也是造成 
该区域氮、磷、钾养分含量出现差异的重要原因 ${ }^{[28-29]}$ 。值得注意的是，20世纪 50 年代以 前, 我国农田磷素处于严重赤字状态，进人 20 世纪 60 年代后开始普遍施用磷肥，到了 20 世纪 70-80年代农田中磷素处于盈余状态，有效磷的含量也相应提高 ${ }^{[30]}$ 。本研究中，20 世纪 90 年代以来华北平原引黄灌区农田中有效磷的含量下降了约 $27 \% \sim 65 \%$ ，原因之一可 能是 30 年来农田中磷肥施用量较为稳定，而作物生物量和产量(提高约 $67 \%$ )逐年增长， 作物对土壤有效磷吸收利用增加导致其含量出现下降趋势; 另一个可能的原因是该地区 磷肥施用的不合理，有学者证明了山东省引黄灌区临沂市自 2000 年以后农田不合理施肥 现象严重，尤其是氮磷肥比例严重失调，导致该地区磷素出现亏缺的趋势 ${ }^{[31]}$ 。

\section{参考文献(References):}

[1] SHI W J, TAO F L, LIU J Y. Changes in quantity and quality of cropland and the implications for grain production in the Huang-Huai-Hai Plain of China. Food Security, 2013, 5(1): 69-82.

[2] 孙领. 中国农业自然资源与区域发展. 南京: 江苏科学技术出版社, 1994. [SUN H, SHEN Y Q, SHI Y L, et al. Agricultural Natural Resources and Regional Development of China. Nanjing: Jiangsu Science and Technology Press, 1994.]

[3] 陈印军, 肖碧林, 方琳娜, 等. 中国耕地质量状况分析. 中国农业科学, 2011, 44(17): 3557-3564. [CHEN Y J, XIAO B L, FANG L N, et al. The quality analysis of cultivated land in China. Scientia Agricultura Sinica, 2011, 44(17): $3557-$ 3564.]

[4] 许红卫. 田间土壤养分与作物产量的时空变异及其相关性研究. 杭州: 浙江大学, 2004. [XU H W. Spatial and temporal within-field variability of soil nutrients, corp yield, crop nutrients and their correlation. Hangzhou: Zhejiang University, 2004.]

[5] 吴玉红, 田霄鸿, 侯永辉, 等. 基于田块尺度的土壤肥力模糊评价研究. 自然资源学报, 2009, 24(8): 1422-1431. [WU Y H, TIAN X H, HOU Y H, et al. Preliminary study on the subject concerning fuzzy assessment method of soil fertility based on fieldscale. Journal of Natural Resources, 2009, 24(8): 1422-1431.]

[6] 张俊华,李国栋, 南忠仁, 等. 耕作历史和种植制度对绿洲农田土壤有机碳及其组分的影响. 自然资源学报, 2012, 27 (2): 196-203. [ZHANG J H, LI G D, NAN Z G, et al. Effects of cultivation history and cropping system on soil organic carbon and its components in oasis soils. Journal of Natural Resources, 2012, 27(2): 196-203.]

[7] 赵业婷, 李志鹏, 常庆瑞. 关中盆地县域农田土壤碱解氮空间分异及变化研究. 自然资源学报, 2013, 28(6): 10301038. [ZHAO Y T, LI Z P, CHANG Q R. Study on spatial variability and change of soil alkali-hydrolyzable nitrogen in Guanzhong basin county-level farmland. Journal of Natural Resources, 2013, 28(6): 1030-1038.]

[8] 高祥照, 胡克林, 郭炎, 等. 土壤养分与作物产量的空间变异特征与精确施肥. 中国农业科学, 2002, 35(6): 660-666 [GAO X Z, HU K L, GUO Y, et al. Spatial variability of soil nutrients and crop yield and site-specific fertilizer management. Scientia Agricultura Sinica, 2002, 35(6): 660-666.]

[9] 赵艺, 施泽明, 师刚强. 土壤养分空间变异特征与作物产量关系分析. 农家之友: 理论版, 2010, (8): 6-7, 26. [ZHAO Y, SHI Z M, SHI G Q. Relationship between spatial variability of soil nutrients and crop yield. A Friend of the Peasant Family: Theoretical Edition, 2010, (8): 6-7, 26.]

[10] 陈晨, 梁银丽, 吴瑞俊, 等. 黄土丘陵沟壑区坡地土壤有机碳变化及碳循环初步研究. 自然资源学报, 2010, 25(4): 668-676. [CHEN C, LIANG Y L, WU R J, et al. A preliminary on the change of soil organic carbon and carbon cycling of the slope land in the Loess Hilly-Gully areas. Journal of Natural Resources, 2010, 25(4): 668-676.]

[11] 宋小顺, 李路平, 陈荣江. 河南省新乡市土壤养分施人量与作物产量变化的分析. 贵州农业科学, 2008, 36(3):89-92. [SONG X S, LI L P, CHEN R J. Analysis on the relationship between application quantity of soil nutrient and crop yield in Xinxiang city, Henan. Guizhou Agricultural Sciences, 2008, 36(3): 89-92.]

[12] 全国农业技术推广服务中心. 华北小麦玉米轮作区耕地地力. 北京: 中国农业出版社, 2015. [The National AgroTech Extension and Service Center. The Cultivated Land Fertility of Wheat Maize Rotation Area in North China. Beijing: Chinese Agricultural Press, 2015.]

[13] WALKLEY A J, BLACK I A. An examination of the degtjareff method for determining soil organic matter, and a proposed modification of the chromic acid titration method. Soil Science, 1934, 37(1): 29-38.

[14] BLACK C A, EVANS D D, WHITE J L, et al. Methods of soil analysis. Pt. 1. Physical and mineralogical properties, in- 
cluding statistics of measurement and sampling. Pt. 2. Chemical and microbiological properties. 1965, 499-510.

[15] OLSEN S R. Estimation of available phosphorus in soils by extraction with sodium bicarbonate. Miscellaneous Paper Institute for Agricultural Research Samaru, 1954, 939: 19.

[16] 南京农业大学.土壤农化分析. 北京: 中国农业出版社, 1990. [Nanjing Agricultural University. Soil Agricultural Chemical Analysis. Beijing: Chinese Agricultural Press, 1990.]

[17] ZHANG X B, SUN N, WU L H, et al. Effects of enhancing soil organic carbon sequestration in the topsoil by fertilization on crop productivity and stability: Evidence from long-term experiments with wheat-maize cropping systems in China. Science of the Total Environment. 2016, 562(562): 247-259.

[18] 丁昆仑, 许迪, 蔡林根. 黄河下游地区表层土壤盐分对作物产量的影响. 农业工程学报, 2004, 20(2): 88-92. [DING K L, XU D, CAI L G. Effects of surface soil salinity on crop yield in areas of the lower reaches of the Yellow River. Transactions of the CSAE, 2004, 20(2): 88-92.]

[19] 吴凯, 谢明. 黄淮海平原农业综合开发的效益和粮食增产潜力. 地理研究, 1996, 15(3): 70-76. [WU K, XIE M. The synthetical benefits and the potential of grain yield-increasing during agricultural. Geographical Research, 1996, 15(3): 70-76.]

[20] 张运龙. 有机肥施用对冬小麦一夏玉米产量和土壤肥力的影响. 北京: 中国农业大学, 2017. [ZHANG Y L. Effect of organic fertilizer on yield of winter wheat-summer maize and soil fertility. Beijing: China Agricultural University, 2017. ]

[21] 聂良鹏, 郭利伟, 牛海燕, 等. 轮耕对小麦一玉米两熟农田耕层构造及作物产量与品质的影响. 作物学报, 2015, 41 (3): 468-478. [NIE L P, GUO L W, NIU H Y, et al. Effects of rotational tillage on tilth soil structure and crop yield and quality in maize-wheat cropping system. Acta Agronomica Sinica, 2015, 41(3): 468-478.]

[22] 邵云, 王小洁, 张紧紧, 等. 小麦一玉米轮作区耕作及培肥方式对麦田土壤养分和小麦产量的影响. 华北农学报, 2013, 28(3): 152-158. [SHAO Y, WANG X J, ZHANG J J, et al. Effects of tillage and fertilizer on soil nutrient and wheat yield in wheat-corn rotation area. Acta Agriculturae Boreali-Sinica, 2013, 28(3): 152-158.]

[23] HAN D R, M WIESMEIER, R T CONANT, et al. Large soil organic carbon increase due to improved agronomic management in the North China Plain from 1980s to 2010s. Glob Chang Biol, 2017, 24(3): 987-1000.

[24] 立宁. 山东省耕地土壤养分数据库建立及其分异特征分析. 济南: 山东农业大学, 2017. [HANG N. Database establishment and differentiation characteristics of soil nutrient in Shandong province. Jinan: Shandong Agricultural University, 2017.]

[25] KENDY E, MOLDEN D J, STEENHUIS T S, et al. Policies drain the North China Plain: Agricultural policy and groundwater depletion in Luancheng county, 1949-2000. Colombo: International Water Management Institute, Research Report 71, 2003.

[26] 方生, 陈秀玲, 范振铎, 等. 旱涝碱咸综合治理与生态环境良性循环. 地下水, 2005, 27(1): 12-15. [FANG S, CHEN X L, FAN Z D, et al. Comprehensive control of drought, waterlogging, salinity and saline groundwater and good circulation of eco-environment. Ground Water, 2005, 27(1): 12-15.]

[27] 赵广帅, 李发东, 李运生, 等. 长期施肥对土壤有机质积累的影响. 生态环境学报, 2012, 21(5): 840-847. [ZHANG G S, LI F D, LI Y S, et al. Effects of long-term fertilization on soil organic matter accumulation. Ecology and Environmental Sciences, 2012, 21(5): 840-847.]

[28] 初明光, 王激清, 马文奇, 等. 山东省粮食作物的化肥施用状况分析. 中国土壤与肥料, 2006, (2): 12-15. [CHU G M, WANG J Q, MA W Q, et al. Analysis of fertilizer application on grain crops in Shandong province. Soil and Fertilizer Sciences, 2006, (2): 12-15.]

[29] 肖建军, 崔荣宗, 魏建林, 等. 山东省粮食主产区农户施肥行为调查分析: 以德州市平原县为例. 山东农业科学, 2014, (12): 84-87. [XIAO J J, CUI R Z, WEI J L, et al. Investigation and analysis of farmers' fertilization behavior in major grain producing area of Shandong province: A case study in Pingyuan county of Dezhou. Shandong Agricultural Sciences, 2014, (12): 84-87.]

[30] 鲁如坤. 中国农业中的磷. 中国磷肥应用研究现状与展望学术讨论会论文集, 2005: 19-30. [LU R K. Phosphorus in agriculture of China. The Science Colloquium Papers of the Status and Prospect of Phosphate Fertilizer Application in China, 2005: 19-30.]

[31] 郭玉玲, 姜启双. 临沭县耕地有效磷含量状况及生产对策. 现代化农业, 2015, (2): 9-10. [GUO Y L, JIANG Q S. Status of available phosphorus in cultivated land and production countermeasures in Linshu county. Modernizing Agriculture, 2015, (2): 9-10.] 


\title{
Spatio-temporal patterns of the grain yield and quality of agricultual soil resources in the irrigated area of the Yellow River in the North China Plain
}

\author{
TAO Wen ${ }^{1}$, ZHANG Xu-bo ${ }^{2,3}$, SUN Zhi-gang ${ }^{2,3,4}$, LI Shi-ji ${ }^{2,3}$, LIU Xiao-jie ${ }^{2}$, \\ ZHANG Chong-yu', OUYANG Zhu ${ }^{2,3}$, CHENG Sheng-kui ${ }^{2,3}$ \\ (1. Agricultural College of Guizhou University, Guiyang 550025, China; 2. Key Laboratory of Ecosystem \\ Network Observation and Modeling, Institute of Geographic Sciences and Natural Resources Research, CAS, \\ Beijing 100101, China; 3. College of Resources and Environment, University of Chinese Academy of Sciences, \\ Beijing 100049, China; 4. Zhongke Shandong Dongying Institute of Geography, Dongying 257509, Shandong,
} China)

\begin{abstract}
Understanding the spatial and temporal variations of crop yield and soil nutrient can optimize the agricultural resources utilization and sustain the agro-productivity, which is of great significance for agricultural production activities. In this study, the quality monitoring data of crop yield and soil nutrients were used to analyse the evolution of crop yield and the spatial distribution of soil organic matter and other nutrients in the irrigated area at the lower reaches of the Yellow River in the North China Plain. The results showed that there were significant spatial and temporal differences in the level of agricultural productivity within the irrigated area. Since the late 1980s, the overall level of farmland productivity had been on the rise. The high yield field of winter wheat was distributed in Qihe county in the north part and the three counties in the south part of the lower reaches of the Yellow River with a range of 6084.0- $6861.0 \mathrm{~kg} / \mathrm{hm}^{2}$. The spatial distribution of summer maize yield showed that the intermediate area was higher than the two sides, and the yield of Qihe county was the highest with the yield of $7524.0 \mathrm{~kg} / \mathrm{hm}^{2}$. The lowest yields of winter wheat and summer maize were found in Dongying county, which were 4705.5 and $5092.5 \mathrm{~kg} / \mathrm{hm}^{2}$ respectively. The distribution of organic matter and nutrient of farmland in the irrigated area had obvious spatial and temporal differences. The highest organic matter content and available potassium were observed in Dezhou, being $16.30 \mathrm{~g} / \mathrm{kg}$ and $202.40 \mathrm{mg} / \mathrm{kg}$, respectively. The highest total nitrogen content was in Zibo, being $1.17 \mathrm{~g} / \mathrm{kg}$. The highest phosphorus content was in Tai'an, being $34.56 \mathrm{mg} / \mathrm{kg}$. However, the lowest contents of organic matter, total nitrogen and available phosphorus were observed in Dongying, being $9.90 \mathrm{~g} / \mathrm{kg}, 0.60 \mathrm{~g} / \mathrm{kg}$ and $19.10 \mathrm{mg} / \mathrm{kg}$, respectively. The results suggested that the level of agricultural productivity in the irrigated area had been continuously improving, which indicated that a great potential of agricultural productivity still exists. In addition, identifying the spatial difference of nutrient distribution can give the guidance to design the reasonable fertilization strategies for precision agriculture, and higher and more stable productivity.
\end{abstract}

Keywords: irrigated area of the Yellow River; crop yield; soil quality; organic matter; soil nutrient 